\section{7. 新しい保育器（自動反比例制御保育器）}

新潟大 産科丵人科

千村哲 朗

目的：未熟坚保育における従来の Isolette 型保育器の 器内温度環境の制御方法は, manual thermostat cont rol であり, 不安定な熱平衡を示寸未熟巟々くに $1500 \mathrm{~g}$ 以下の低出生体重児の体温制御方法上しては不満足な ものである.アメリカにおける輻射熱源による servocontrol incubator が未熟胃死亡摔孝減少させたこ上 が報告されて以来, 過去10年間に㧍ける諸家の研究で， 体温直接制御方式が優れた物理的特性上臨床成績在示 すことが報告された。これらの矨見にも上づいて， Electronics 技術の導入による保育器内温度の新しい 自動制御機構を储えた保育器高開発した。

方法: 器内温度制御は, 自動制御でありその特徴は児 皮膚温 $36^{\circ} \mathrm{C}$ set point 上し, それよりの偏善 upper or lower deviation に対応し, 保育器内温度を文比例 制御 inverse proportion coutrol 老的としている。 反比例制御機構の器内温上罗皮膚温の特性関係は、電 子設定值線で示される。

成績：M. T. C と I. P. C に扔ける保育器内環境温度 について，その作動グラフによる比較をおこない，ま た児体温変動を雨制御下で比較し，I.P.C機構の寸ぐ れた特性を認めた. I. P.C. 機構での未熟児体温の経 日変動は $1 / 3$ 以下であり, 保育環境温度の微細な control が児の熱損失を減少せしめ，その結果末熟韭死亡 率を M.T.C.に比し $1 / 2$ 以下に減少させている. また 末熟览の発育に好成績をもたらしている.

結論：この反比例制御機構が, 未熟児とくに $2000 \mathrm{~g}$ 以 下の低出生体重児の保育における環境温の制御機構々 して優れたものであり，未熟巟死亡率を減少させてい 万.

\section{8. 新しい Ether 気化器 “E-retta” の開 発について}

\author{
和歌山県医大 麻醉科 \\ ○田村治夫太田又夫 \\ 上山英明
}

目的：今回対温度自働調節, Dial-Set 式気化濃度標 示機構を俑えた新しいEther気化器“E-retta”至開発 し満足す心゙き結果を得た。

構造・機能：気化による気化槽温下降への対策上し て，水槽を附設し，かつBi-metalによる対温度変動 自動調節機構および Dia!による気化濃度標示方式を 採用し，以下の3 項目について検討した，1）室温変 動による父化〜水槽温変動. 2) 一定室温～Gas 流量 下, 3 20\% Dial-Set 時の Ether 気化濃度，3）一定 室温, Gas 流量 1 ～10 l/min 下における 3〜20\% Dialset 時の Ether 気化濃度.なお, Ether 濃度の測定に は, Beckman GC-2 A Gaschromatograph (Carrier, Ga ; He, Column; Polyethylene Glycol-1000, Detector； T. C; D.) 存使用した.

成績：1）室温の急速 $\left(5.13^{\circ} \mathrm{C} / \mathrm{min}\right)$, 緩速 $\left(0.12^{\circ} \mathrm{C}\right.$ min) 変動により気化槽温はそれぞれ, 最高 $0.34,0.06$ ${ }^{\circ} \mathrm{C} / \mathrm{min}$ の变動勾配を示した。この際いずれも気化槽 温は, 水槽上部よりもむしろ下部温と, $0.25 \pm 0.17$ $0.23 \pm 0.11^{\circ} \mathrm{C}$ 差で近似した。 2) 室温 $23.0^{\circ} \mathrm{C}$, Gas 流 量 $6 \mathrm{l} / \mathrm{min}$ 下では, Dial-Set $3,5,7,11,15,20 \%$ 時 の Ether 気化濃度は，それぞれ $2.92 \pm 0.78,5.14 \pm 0.07$ ， $7.04 \pm 0.5,11.08 \pm 0.27,15.05 \pm 0.17,19.29 \pm 0.12 \%$, 気 化槽温下降勾配は，それぞれ $0.02^{\circ} \mathrm{C} / \mathrm{min}, 0.03^{\circ} \mathrm{C} / \mathrm{min}$, $0.05^{\circ} \mathrm{C} / \mathrm{min}, 0.16^{\circ} \mathrm{C} / \mathrm{min}, 0.26^{\circ} \mathrm{C} / \mathrm{min}, 0.36^{\circ} \mathrm{C} / \mathrm{min}$ て あった. 3）室温 $23.0^{\circ} \mathrm{C}$ 下で $3 \sim 20 \%$ の Dial-Set 時, Gas 流量を 1 より $10 \mathrm{l} / \mathrm{min}$ に変動せしめると, Ether 気化濃度は, $5 \mathrm{l} / \mathrm{min}$ で略々恒定し, 以後 $10 \mathrm{l} / \mathrm{min}$ 迄 の Gas 流量の増加によっても常に, $3.0 \pm 0,5.0 \pm 0$, $7.13 \pm 0.07,11.08 \pm 0.08,15.03 \pm 0.07,20.15 \pm 0.10 \%$ 示した.

結論：“E-retta, は，5 10 l/min の Gas 流量下で は, 室温変動勾配 $5.13^{\circ} \mathrm{C} / \mathrm{min}$, 気化槽温变動勾配 0.36 ${ }^{\circ} \mathrm{C} / \mathrm{min}$ 下においても, 常に恒定した気化能力を示し, その誤差は $0.98 \%$ 以内にとどまった. 